УДК 24-17

АБАЕВА Любовь Лубсановна - доктор исторических наук, профессор, главный научный сотрудник отдела философии, культурологии и религиоведения Института монголоведения, буддологии и тибетологии СО РАН (670047, Россия, Республика Бурятия, г. Улан-Удэ, ул. Сахьяновой, 6; lиваabaeva@mail.ru)

\title{
ДИНАМИКА ФЕНОМЕНА ЭТНИЧНОСТИ И ЭТНОКУЛЬТУРНОЙ КОМПЕТЕНТНОСТИ МОНГОЛЬСКИХ НАРОДОВ В КОНТЕКСТЕ ИДЕЙ И ПРАКТИК СОВРЕМЕННОГО БУДДИЗМА
}

\begin{abstract}
Аннотация. С тех пор как буддийские идеи и практики распространились среди монгольской метаэтнической общности, основные, наиболее популярные и краеугольные буддийские символы проникают в структуру ее традиционных религиозных воззрений и ритуалов. Выступая как трансляторы основных канонов буддизма, эти символы изменили многие структурные составляющие традиционной религиозной культуры и основы повседневного менталитета кочевников. Следует подчеркнуть, что в самом начале каждая религиозная и местная традиция различных монгольских родов и племен в синхронном и диахроническом аспектах пыталась трансформировать и адаптировать эти буддийские символы в соответствии со своими более ранними традиционными религиозными символами. При этом ни синтаксис, ни семантика, ни прагматика этих сложных буддийских семиотических систем не нарушались. Несомненно, этническая идентичность и этнокультурная компетентность монгольских народов лежат в контексте их кочевого образа жизни со всей сложной системой их мировоззрения, знаний, воображения, умений и традиций, ценностных материальных и духовных ориентаций. Однако динамика их этнической ориентации, идентичности и культурной компетентности выявляет их религиозную культуру, находящуюся в русле буддийских идей и практик.
\end{abstract}

Ключевые слова: динамика, этничность, этническая/традиционная религиозная система, этнокультурная компетенция, буддизм, настоящее время

П роцессы эволюции феноменов идентичности и культурной компетентности этносоциальных организмов (социумов) в целом и их индивидов в частности до сих пор считаются актуальными, поскольку все еще нуждаются в адекватном философско-антропологическом осмыслении. Именно эти феноменальные и уникальные парадигмы этнической культуры чаще всего остаются вне рамок многих исследований в контексте развития мегасоциальных процессов. Глобализационные и интеграционные процессы, происходящие в современном мире, несомненно, оказывают трансформирующее воздействие на мировоззренческие и поведенческие сферы любой этнокультурной традиции, в какой-то степени изменяя ее культурную идентичность и традиционные системы ценностей. И хотя интегративные процессы любого сообщества касаются экономических, политических параметров конкретного сообщества, в результате все же меняется и вектор их традиционных, социальных и культурных характеристик. В первую очередь, как правило, инициаторами и инспираторами подобных изменений и трансформаций являются элиты конкретных этнических сообществ, которые тем самым обусловливают трансформацию традиционного мировоззрения, изменяя специфику культурного генома, ядром которого является геном ценностных ориентаций.

Территориальное и культурное пространство монгольской метаэтнической общности - монгольского суперэтноса - в современный период представляет собой многообразное этномонгольское сообщество в Китайской Народной 
Республике, собственно монгольское сообщество в Республике Монголия и две монгольские этнические общности в России. Генезис культурной идентичности монгольской метаэтнической общности - это Великая степь с ярко выраженной кочевой цивилизацией, мировоззрением и мировосприятием кочевников, выработавших специфическую форму этнической психологии, кочевой ментальности и традиционных ценностей. В качестве общего культурного наследия среди всех монгольских народов сохраняются основные элементы кочевой цивилизации: знаки, символы, язык, ценности, правила кочевого образа жизни, социальные нормы, социальные санкции, представления о мифологическом и реальном, поведенческие нормы, этикет, обычаи, традиции, ритуалы.

Культурная идентификация элиты в определенные исторические моменты трансформирует свою традиционную структуру в соответствии с существующей системой этнокультурного окружения, естественным и эволюционным образом сокращая и изменяя при этом прежние мотивации и ценности, обретая многие характеристики урбанизированного социума. Так, известный этносоциолог М.Н. Губогло пишет: «Постановка вопроса об идентичности, т.е. об обретении новых или переосмыслении прежних идентичностей в ходе трансформационных процессов, служит предтечей для другой, более важной проблемы - каким образом и в каких масштабах происходили изменения» [Губогло 2003: 69]. В рамках проекта «Социокультурный облик бурятской диаспоры в Китае» в 2007 г. аспирантом М.Н. Губогло и Т.Н. Абаевым была «предпринята попытка исследования монгольских этнических групп в г. Хулун-Буир Автономного района Внутренней Монголии КНР. Основная цель проекта заключалась в исследовании этносоциальной структуры монгольских этнических групп, населяющих этот регион, и в попытке проанализировать развитие их этнокультурных традиций, а также вывести их этносоциальный и этнокульурный потенциал, создавшийся в инокультурном и иноэтническом окружении и влиянии» [Абаев 2007: 127]. В результате полевых исследований Т.Н. Абаев приходит к выводу, что буряты Шэнэхэнского балгаса, дагуры Дагурского сомона аймака Баян-Тала (в основном Цицикар и Морин-Дава), баргуты-шинэ и хучин («старые» и «новые») Старобаргутского, Западного и Восточного хошунов с центром в г. Баян-Хурэ и другие монгольские этносы и группы этого региона «не утратили свою основную хозяйственно-культурную доминанту - скотоводство (причем они являются одним из основных поставщиков натуральных мясных продуктов в Китае), а значит, и их этнокультурный потенциал все еще достаточно высок, так как многие элементы традиционной культуры не подверглись ассимиляции» [Абаев 2007: 131]. Наши собственные полевые исследования в районе Внутренней Монголии КНР подтверждают эти данные. Единственное, что хотелось бы добавить и отметить в данном контексте, это то, что мировоззрение и мировосприятие элиты монгольских общностей Внутренней Монголии Китая (баргутов, хорчинов, джалайт и бурят в Хулунбуирском аймаке Внутренней Монголии Китая; хорчинов в Джеримском аймаке; харчинов, ара-харчинов, огнютов, хэшигтэнов, тумэтов, баринов в Жоудасском аймаке; узумчинов, хучинов, абага, абаганаров в Шилингольском аймаке; чахаров в Чахарском аймаке; уратов, дурбэн хухэтов, дархан-мянгатов в Уланцабском аймаке и ордосов в Ехэ-Чжоуском аймаке, а также упомянутых Т.Н. Абаевым дагуров, баргутов, хорчин, харчин, дунсянь, баоянь, бурят и многих других в смысле культурной идентичности как «не-ханьских» этносов Китая) хотя и последовательно продолжают гомогенизироваться с доминирующей китайской социальной и культурной идентичностью, но все же остаются в контексте буддийских практик в ее общемонгольском варианте. 
При этом среди элиты бурятской диаспоры в мифологическом и реальном сознании представителей элитарного буддийского духовенства во Внутренней Монголии КНР фиксируется четкая тенденция возвращения на историческую родину - в современную Россию, несмотря на то что экономические условия проживания в Китае и в России, куда они, возможно, вернутся, однозначно несопоставимы. По этнографическим данным этнолога Д.Д. Нимаева, в некоторых провинциях КНР дисперсно проживают такие этнические монгольские группы, как горлосы - в Хэйлунцзяне, тумэты - в Ляонине, кукунорские монголы - в Цинхае и в провинциях Ганьсу и Юньнань. При этом ученый приводит новые количественные данные о численности населения Внутренней Монголии КНР - 22 млн чел., из них «не-ханьского» (не-китайского) происхождения - 4 млн, 3,3 млн из которых относятся к монгольской метаэтнической общности. Общая численность монголов в Китае, добавляет автор, ссылаясь на И.А. Жоголева, согласно данным 4-й переписи населения 1992 г., - 4802407 чел. [Нимаев 2007: 17].

При этом каждая этническая культура воспринимала и анализировала этнокультурные реалии и феномены других культур с точки зрения своих исторически и генетически традиционно устоявшихся парадигм. Такой классический вектор направленности обычно традиционен и мало поддается большим изменениям. Фундаментальные ценностные структуры собственных этнокультурных традиций и связанные с этим собственная этническая сущность и проявленность, а также этническая, социальная и культурная идентичности всегда, как правило, выступают доминирующими и этнофиксирующими маркерами в оценке и анализе других культур. Так, например, элита китайской культуры, относящейся к древним и осевым культурным цивилизациям (как и римская, также именуемая «осевой» в культурной антропологии), с некоторым высокомерием относилась к культурным реалиям своих сопредельных территорий, населенных этносами-кочевниками со специфическими этнокультурными традициями, передвижными жилищами, своеобразной системой культуры питания, и не воспринимала феномен культурной идентичности монгольской метаэтнической общности, населяющей Великую степь, адекватно, относя их со своей «высокой колокольни» к «варварским». Относительно китайской этнокультурной традиции с точки зрения языка культуры в процессе эволюции общения возникло недопонимание некоторых объектов и субъектов монгольской этнокультурной традиции, т.к. исторически китайская традиционная культура - это земледельческий вид хозяйствования, с оседлой жизнедеятельностью и системой жизнеобеспечения, тогда как монгольская этнокультурная традиция - это кочевая цивилизация с достаточно подвижной, динамичной и мобильной системой передвижения и особой структурой жизнеобеспечения и жизнедеятельности. Здесь, естественно, фиксируются моменты непонимания и тенденции неприятия многих этнокультурных элементов, недоступных для адекватной интерпретации, т.к. в культуре земледельческих народов отсутствуют эквивалентные феномены, а значит и термины для обозначения того или иного культурного феномена кочевых культур [Абаева 2018: 68-71].

Совсем иная структура культурной идентичности среди элиты Монголии, где в результате длительных этнических и этносоциальных процессов с многочисленными количественно и доминирующими в этнокультурном отношении халха Великую степь населяли племенные объединения западных монголов - ойраты, дариганга, хотогойты, сартулы, узумчины, хорчины, чахары и др. В практически моноэтнической Монголии культурная компетентность элиты общества происходила в русле урбанизационных процессов. При этом культурная идентификация и самоидентификация представителей монголь- 
ской общности, например во Внутренней Монголии, происходила на уровне китайской оседлой культуры и культуры кочевников. Так, в Синьцзянском автономном районе КНР - китайская оседлая культура и культура как собственно монгольских кочевников, так и кочевая культура тюркских этносов; в Монголии - маньчжурская культура и монгольская кочевая культура, в основном в условиях моноэтнической структуры; в Бурятии и Калмыкии - славянские этнические сообщества и бурятский и калмыцкий этнический стереотип кочевой цивилизации. Традиционные ценности метаэтнической монгольской общности в виде поведенческих, мировоззренческих, мифологических и мифотворческих стереотипов подверглись меньшей степени трансформации, изменившись лишь с эволюцией политической и экономической структур каждого конкретного монгольского этноса. Аксиологическая структура кочевой культуры осталась практически на уровне традиционной, лишь в существующие этнокультурные и конфессиональные модели были внесены некоторые инновационные буддийские символы и практики. В современный период во всех монгольских сообществах всей монголосферы также почитаются ханы до и после Чингисхана. В культурном пространстве своего бытия монгольская метаэтническая общность, как правило, сакрализировала многие существовавшие вокруг ландшафтные и природные объекты - горы, озера, реки, деревья и т.д. К сакральным символам монгольские сообщества относили также и небесную сферу, почитая Солнце, Луну, звезды, созвездия, небесные светила, Полярную звезду (Алтан Гадас), Большую и Малую Медведицу (Долон Убэгэн), Млечный путь, Плеяды (Мичит), Венеру (Цолмон). В структуру астральных и сакрализованных мифов монгольских народов также было включено и Небо - как категория безначальная, и значит бесконечная, несотворенная, владеющая судьбами мира монгольского сообщества и его отдельных индивидов, повлекшая за собой возникновение тэнгрианского феномена.

С распространением буддизма во всей монголосфере религиозными символами стали Будда, Цзонхава, Далай-лама, Чжэбзун-Дамба хутухта, Белая и Зеленая Тара, а также многочисленный пантеон буддийских бодхисатв и защитников веры. Необходимо также отметить, что в некоторых локусах монгольского мира конфессиональная идентичность его представителей пролегает в рамках как шаманских и неошаманских традиций, так и в рамках буддийской религиозной культуры. Амбивалентная культурная идентичность наблюдается практически у всех представителей монгольской метаэтнической общности не только в результате кросс-культурных взаимовлияний, но и в силу высокой степени их адаптационных этнокультурных возможностей, выработанных еще в период Монгольской империи. Как известно, амбивалентная идентичность в векторе развития этнокультурных характеристик является следствием продолжительных контактов с инокультурной средой. Элита монгольских этносов Китая одинаково хорошо адаптировала существующие в разные хронологические периоды китайские этнокультурные реалии, в т.ч. и язык, оставаясь все же в векторе общемонгольского принципа адаптации буддийских идей и практик.

Бикультуральными, а следовательно и билингвальными, вовлеченными в канву российских этнических, социальных и политических реалий являются также элиты калмыков и бурят в России. Примечательно, что, в отличие от монгольских этносов Китая, где на китайском языке фактически свободно говорит только элита, представители бурятского и калмыцкого этносов свободно говорят на русском языке, в какой-то степени демонстрируя этнокультурную индифферентность к родному языку. Культурная индифферентность бурят и 
калмыков свидетельствует о практически завершившемся процессе аккультурации этих этносов в поликультурном пространстве России. Длительный процесс взаимодействия с русской культурой и представителями староверческих (семейских) и казачьих этнокультурных реалий, пришедших в Восточную и Южную Сибирь вместе с их носителями, несомненно, обогатили культурную компетентность бурятского этноса, в какой-то мере спровоцировав высокий уровень этнокультурной адаптации, а также коллективную и индивидуальную толерантность.

Культурная идентичность и конфессиональная компетентность калмыцкого этноса в России достаточно многослойна и сложна. Исторически они являются выходцами из Западной Монголии, осевшими на современной территории проживания лишь в XVII в. Элита калмыцкого сообщества не теряла связей со своими сородичами как в Западной Монголии, так и в Синьцзяньском автономном округе КНР, оставаясь при этом адептами учения традиции школы гелуг Далай лам XIII и XIV. Небезынтересно, что, будучи великолепными всадниками, они успешно адаптировались в период Российской империи, проходя военную службу в охране царской фамилии. Годы репрессий в СССР разбросали калмыцкий этнос практически по всему миру. Калмыцкие диаспоры населяют США, Францию и другие европейские страны. В данном случае культурная идентичность элиты этих диаспор по отношению к современным буддийским идеям и практикам достаточно высока, т.к. не были потеряны устои их конфессиональной идентичности как представителей монгольской метаэтнической общности.

Говоря о культурной идентичности современной элиты бурятского и калмыцкого этносов, необходимо отметить, что в сферу их культурной компетентности не входит знание старомонгольского вертикального письменного языка (Хуушан Монгол), алфавит которого был инспирирован уйгурской вертикальной письменностью, а также старокалмыцкого Тод Бичиг (Ясное письмо), созданного представителем элитарного буддийского духовенства Зая Пандитой. А ведь именно на эту общую для монгольских народов письменность в свое время была переведена практически вся буддийская каноническая литература.

Работа выполнена в рамках государственного задания ИМБТ СО РАН по проекту ХІІ.191.1.3. «Комплексное исследование религиозно-философских, историкокультурных, социально-политических аспектов буддизма в традиционных и современных контекстах России и стран Центральной и Восточной Азии», номер госрегистрации № AAAA-A17-117021310263-7.

\section{Список литературы}

Абаев Т.Н. 2007. Этносоциальная структура и этнокультурный потенциал монгольских диаспор в г. Хулун-Буир АРВМ КНР. - Диаспоры в современном мире. Улан-Удэ: Изд-во БГУ. 287 с.

Абаева Л.Л. 2018. Религиозная культура монгольских народов в векторе буддийских традиций. Улан-Удэ: Бурят-Монгол ном. 367 с.

Губогло М.Н. 2003. Вызовы глобализации и искушения идентификации. Идентификации идентификаций: этносоциологические очерки. М.: Наука. $763 \mathrm{c.}$.

Нимаев Д.Д. 2007. Монгольские народы: этническая история и современные этнокультурные процессы: учебное пособие. Улан-Удэ: Изд-во БГУ. 145 с. 
ABAEVA Liubov' Lubsanovna, Dr. Sci. (Hist.), Professor, Chief Researcher of the Department of Philosophy, Cultural Anthropology and Religious Studies, Institute for Mongolian, Buddhist and Tibetan Studies, Siberian Branch of Russian Academy of Sciences (6 Sakhyanovoj St, Ulan-Ude, Republic of Buryatia, Russia, 670047; luba-abaeva@mail.ru)

\title{
DYNAMICS AS OF THE ETHNICITY AS OF THE ETHNO- CULTURAL COMPETENCE OF THE MONGOLIANS IN THE CONTEXT OF THE MODERN BUDDHIST IDEAS AND PRACTICES
}

\begin{abstract}
Buddhist symbols from the time, when Buddhism was spread among the Mongolian people, penetrated and changed the main components of their traditional religious culture and the fundamentals of the ordinary mentality of the nomads. Buddhist symbols represented for a definite period as translators and interpreters the Buddhist popular ideas and rituals. One must underline there, that at the very beginning, each religious and local tradition of the different Mongolian clans and tribes, in synchronically and diachronically aspects, tried to transform and adapt those Buddhist symbols according to their earlier traditional religious symbols, as a whole, without breaking syntaxes, neither semantics, nor pragmatics of these complicated Buddhist semiotic systems. No doubt, the ethnical identity and cultural competent sphere of the Mongolians lie upon the context of their nomadic lifestyle with all the complex system of their worldview, knowledge, imaginations, skills and traditions of different valuable and spiritual orientations. However, the dynamics of their ethnic orientation and cultural identity in the modern time show the fact that their religious culture deals mainly with Buddhism.
\end{abstract}

Keywords: dynamics, ethnicity, ethnical religious/traditional system, cultural competence sphere, Buddhism, Modern time

НАСОНОВА Людмила Ивановна - доктор философских наук, профессор; профессор Московской академии Следственного комитета РФ (125080, Россия, г. Москва, ул. Врубеля, 12; lynх.nasonova@ yandex.ru)

\section{ЭВОЛЮЦИЯ И ВЗАИМОПРОНИКНОВЕНИЕ ПРИВАТНОСТИ И ПУБЛИЧНОСТИ}

\begin{abstract}
Аннотация. Основная тема статьи - рассмотрение приватности не как исключительно правовой, но как общесоциальной категории, содержание которой имеет множество аспектов, в т.ч. соотношение $c$ собственной социальной оппозицией - публичностью. Данное соотношение представляется той сферой, где происходит эволюция как приватности, так и публичности, проявляющаяся в ряде феноменов. Важнейшим представляется взаимопроникновение обеих ипостасей человеческого бытия, причем особый интерес вызывают их современные формы на фоне изменений всех сфер общественного производства в связи с глубоким проникновением в них информационных технологий. Последние, во-первых, инициируют радикальные изменения приватных, личностных интенций и, во-вторых, придают деятельности публичных институтов управления новый, нелинейный и вероятностный характер.
\end{abstract}

Ключевые слова: эволюция приватности, взаимосвязь и взаимопроникновение приватного и публичного, деприва(тиза)ция

Үддержание понятий приватности и публичности задавалось постоянно меняющимся в истории соотношением меры активности общества в целом и его институтов, с одной стороны, и меры возможности свободы деятельности отдельного, частного человека в его индивидуальности. Именно феномены 